УДК 331.108.2, 331.361

JEL: M12; M53

Halyna BABIAK,

$\mathrm{Ph}$. D. in geography, Associate Professor, Department of Management, Public Administration and Personnel, Ternopil National Economic University

Iryna ILLIASH,

$\mathrm{Ph}$. D. in geography, Associate Professor, Department of Management, Public Administration and Personnel, Ternopil National Economic University

\title{
IMPROVEMENT OF ENTERPRISE STAFF TRAINING SYSTEM
}

The article substantiates the importance of improving the personnel training system of the company under the current competitive conditions. It has been found that providing continuous training and increasing the level of professional and personal competences allows to ensure high results of work, to maintain competitiveness of the firm and the staff both in the internal and external labor markets. Thus, it is substantiated that the vocational training system is a very important tool for effective management of the organization. The peculiarities of the organization and conducting of professional training at the enterprise of the "Pearl of Podillya" Ltd., in particular: the role of certification in the process of identifying the need for professional development; methods of performance appraisal at a particular enterprise; the first attempts to organize the learning process with the help of a specially created unit in the personnel management structure; the nature of the forms of training applied at the enterprise depending on the needs and results of training, positions and sphere of activity of employees; the importance of in-house trainings and seminars, special certified development programs, internships and mentoring in the training and professional development of employees of the enterprise are revealed. Problems in the process of organization and training of personnel at the enterprise are found out, namely: chaotic and poor planning of training results, limited financial resources, insufficient connection between training and motivation (material and moral) of employees. It is suggested to: take into account the experience of other countries and successful companies in the field of personnel development; provide a transparent system for the relationship between certification, learning outcomes, career advancement and remuneration; implement staff rotation, individualized vocational training planning and continuing education.

У статті обтрунтовано важливість удосконалення системи навчання персоналу підприємства за сучасних конкурентних умов. 3 'ясовано, щзо забезпечення постійного навчання та підвищення рівня професійних та особистих компетенцій дозволяє забезпечувати високі результати праці, зберігати конкурентоспроможність фірми та самого персоналу як на внутрішньому, так $і$ на зовнішньому ринках праці. Таким чином обтрунтовано, щуо система професійного навчання є дуже важливим інструментом ефективного управління організачією. Виявлено особливості організації та проведення професійного навчання на підприємстві ТОВ “Перлина Поділля”, зокрема: роль атестації у процесі виявлення потреби в професійному розвитку; методи проведення атестації на конкретному підприємстві; перші спроби організації процесу навчання за допомогою спеціально створеного підрозділу у структурі управління персоналом; сутність форм навчання, щзо застосовуються на підприємстві залежно від потреби $i$ результатів навчання, посад та сфери діяльності прачівників; важливість внутрішньо фірмових тренінгів та семінарів, спеціальних сертифікованих програм розвитку, стажувань та наставництва у прочесів навчання та підвищення кваліфікації працівників підприємства. Виявлено проблеми у прочесі організації та проведення навчання персоналу на підприємстві, а саме: хаотичність та слабке планування результатів навчання, обмеженість фінансових ресурсів, недостатній зв'язок між навчанням і мотивацією (матеріальною та моральною) працівників. 
Запропоновано: врахувати досвід інших краӥн та успішних компаній у сфері розвитку персоналу; забезпечити прозору систему взаємозв'язку між атестацією, результатами навчання, кар'єрним ростом та винагородою за працю; впровадити ротаџію кадрів, планування професійного навчання за принципом індивідуальності та безперервне навчання.

Keywords: vocational training; staff development; attestation; forms and methods of teaching; lifelong learning; $H R$.

Ключові слова: професійне навчання; розвиток персоналу; атестачія; форми $і$ методи навчання; безперервне навчання; управління персоналом.

Формули: 0, рис.: 0, табл.: 0, бібл.: 8 .

Formulas: 0, fig.: 0, tabl.: 0, bibl.: 8 .

Formulation of the problem in general form and its relation to important scientific and practical tasks. The integration of Ukraine into Europe is an important step for today. However, it provides new requirements, including for the vocational education system. Continuous development of science and technology requires the continuous training for modern employees, which is the basis of high competitiveness of the enterprise in the market.

The constant modernization of the economy also requires changes in the strategies of companies. Such are the challenges of today. Adaptation to these new conditions forces to change both the personnel management system and the staff training system as part of the personnel management process. In view of the above, the mentioned problem is extremely important for modern enterprises, because the efficiency of our economy as a whole depend on them.

The main components of a successful company are the personnel, its constant professional training, ensuring of its proportional and dynamic development, work adaptation, career planning, the opportunity to self-fulfill as a person, a well-chosen leadership style, preparation of a reserve of managers.

The most important factor in the effective functioning of the enterprise in the labor market is the ability and willingness of workers to continuous education, because high results can only be achieved when people have certain knowledge and skills that will provide competitive ability in the labor market.

Unfortunately, there is no purposeful state policy in the field of staff training for now, so consideration of this issue is quite important for both the state and the enterprise itself.

An analysis of recent research and publications that have started to solve the issue. The analysis of the recent research shows that one of the most important elements of the personnel support of the enterprise is the staff development and training as its component. L. Balabanova, E. Varlamova, N. Volodina, T. Girchenko, O. Demchenko, I. Zakov, T. Kiryan, V. Kozlov, P. Magura, O. Nestorenko, L. Novakovska, O. Sardak, V. Skakun, M. Yakovenko and others explored this problem in their works. These scientists are common in thought the staff training system is a very important tool for effective management of the organization.

The purpose of the article. Investigation of the current system of training of the personnel of the enterprise and outlining ways of its improvement.

Outline of the main research material. Personnel potential of any enterprise is the most important strategic factor that determines the success of all its activities. One of the priority areas of personnel policy should be the formation of high-quality human resources through the admission of qualified professionals, their development through systematic training, advanced training or retraining.

As the staff is an integral part of the successful operation of "Perlyna Podillya" Ltd., the administration must constantly be responsible for the efficiency of its management, training and retraining. The production and labor processes at the enterprise require high-quality and efficient work related to the use of modern domestic and foreign machinery and mechanisms. This, in turn, dictates the need for further growth of the role of qualified staff capable of solving technical and technological, financial and economic, personnel, motivation, and ensure effective work of the team.

Staff training is a continuous process, accompanying the employee throughout his or her work activity. But it loses its focus and meaning to its performers without defining the goals and training needs. 
The determination of the need in professional development of employees at the "Perlyna Podillya" Ltd. is made partly by the HR-department and the management of the enterprise. According to the management, the main factors for the staff training are: the development of new technologies and the use of the latest technology in the industry, the development of new products and types of activities, the external environment, changes in the structure.

Unfortunately, the management does not support the idea of applying the newest methods of personnel development due to lack of funds.

The main method of determining the need in staff training of "Perlyna Podillya" Ltd. is their certification. Management considers this to be a realistic way of both testing knowledge and skills of employees, their abilities.

It is clear that the certification helps the employer to identify the relevant skills, professional knowledge of the employees to the established requirements, qualitative characteristics of the profession according to job instruction and others normativ legal acts of the company.

In process of carrying out the certification, depending on the position and estimated criterion in the "Perlyna Podillya" Ltd. [8, 31]: experts evaluate the employee who passes the certification according to the relevant criteria and scale. Often, an employee is asked a number of questions by Modeling Work Situation in writing. One is offered to find a solution in a simulated situation typical of the workplace he/she occupies. Management gives the task to the certified employee to independently develop ways to solve a certain entrepreneurial problem. An expert interview is also conducted with the employee. Testing has become increasingly widespread, when an employee is asked to take a professional test.

At the end of the appraisal of each employee, one's results are recorded in the attestation sheet, which is kept in his/her personal file throughout the period of work in the company. Based on the certification, the HR department prepares a report for senior management.

In general, the management of the company sees in the personnel appraisal a tool for managing it. We believe that giving preference only to certification is not a sufficient step to determine the professional competencies and personal qualities of employees.

The planning of staff training at "Perlyna Podillya" Ltd. is underdeveloped and needs considerable improvement. There is no clear training strategy and, in a way, there is no cost strategy to invest in the staff training of the enterprise.

At the same time, the personnel training department is starting to emerge at the enterprise. The first steps of this structure is to approve already known forms of personnel training [8]:

1. Internal seminars: information-consulting, practical, problem-design.

2. Internships.

3. Internal trainings, formation of management skills.

4. External seminars, specific tasks or active representation in a specific professional field.

5. Certification programs, maintenance of internal regulatory documents.

6. Independent training, professional development.

7. Mentoring is the main method of training for a newly hired employee of "Perlyna Podillya" Ltd. It is the most developed, already existing form of work with newly hired staff. It provides for streamlining the process of professional competency development, developing the ability to independently and qualitatively perform the tasks assigned to the employee due to a position and adapt it to the company.

Creation a learning system is a time-consuming process. That is why all employees of the "Perlyna Podillya" Ltd., first and foremost senior and middle managers, must clearly understand the goals and objectives of staff training and be aware of its importance in the successful functioning of the enterprise.

Today, the viability of "Perlyna Podillya" Ltd. is determined by its ability to adapt to rapidly changing conditions, its ability to adapt, which necessitates continuous improvement of management based on organizational innovation. Therefore, the company should be interested in increasing the efficiency of work and trying to find new opportunities for development and training of employees even with limited financial capacity of the company.

The development of personnel of the company is still chaotic, there is no clear program of development of each employee. This greatly impedes the staff development processes.

In order to improve the workforce of the company, it is necessary to take into account the experience 
of other countries as well, to introduce a training system that will help the employees to continuously learn and improve their skills. It should also be possible for the enterprise to further look at the cost of training the staff and to engage professionals from other enterprises. An important element is the persistence of the employee in training and in promoting the quality of efficiency. It is neccessery to put in direct dependence on the result of one's attestation, career development and establishment of a salary level.

It is necessary to develop a program of retraining and promotion of qualification of employees in the enterprise of "Perlyna Podillya" Ltd., namely to:

- identify the needs of the enterprise in each type of training;

- develop a training plan;

- choose training centers;

- determine the timing and duration of training;

- occupation topics;

- calculate financial and material and technical support, etc.

The company needs to have a qualified specialist in staff training, who would develop training programs for its employees, conduct practical situations, business games and more.

The main directions of professional training of personnel and transition to an innovative model of economic development in the company should be:

- development of a system of continuous professional training of personnel. This may also include training in production and in-house training;

- the enterprise should stimulate its staff to create and develop innovations that are capable of generating revenue growth and competitive advantage;

- create conditions for career advancement of employees;

- use non-traditional teaching methods with the help of certified software;

- ensuring the stability of the personnel composition, reducing its turnover;

- encouraging the internal competition among cooperators within certain limits, while avoiding conflicting situations.

One of the ways to increase the organization of staff training of "Perlyna Podillya" Ltd. is to introduce staff rotation, which is the presence of employees in different positions, in order to expand their knowledge and practical skills in different directions of work (like this form is applied at "SE Bordnetce-Ukrayina"). It is advisable to conduct such training throughout the year. This time will be enough to familiarize the employee with the scope of activities of the company and its tasks.

As a result of personnel rotation, of "Perlyna Podillya" Ltd. will receive:

- generalist emploees who can work in different workplaces and will be mobile when needed;

- good specialists in the company, who will not need to look beyond its borders; problems.

- such employees will be able to generate new ideas, submit their suggestions for solving current

During the rotation, employees will be able to communicate more, social contacts will arise. This will develop loyalty to the "Perlyna Podillya" Ltd. where they work.

Another way of improving the organization of training of the personnel of the company is its direct attachment to their motivation.

The motivation to study is most often manifested as an external incentive: the threat of punishment or deprivation of other benefits. It is clear that the effectivness of such a model of learning in modern conditions is insufficient, and its form contradicts the concept of personality rights, including the right to self-realization.

Staff training can be one of the essential motivators that will allow both staff to retain for a long time and attract new ones. But such a process is possible only with the right approach, when choosing the most effective methods.

It is advisable to train staff to attach to the enterprise. Therefore, if the purpose is not only to improve the professional skills and motivation of employees, but also to "attach" them, it would be best for the employer to pay for the training of a particular employee in a particular institution. It will be necessary both to retain valuable skilled personnel from the transition to another place of work, and to avoid material losses of the company (when, after obtaining an education, the employee changes work and the company 
actually incurs losses in the amount of training fees).

In "Perlyna Podillya" Ltd. it is necessary to establish a direct correlation between the level of knowledge, the amount of training completed and the growth of wages. In such circumstances, training can become not just an effective way of motivation, but a standard of living. Training will be the most effective means of motivation for those who feel responsible for their own development. That is, training that the employee of the company will feel and need will be especially effective.

The training system should be flexible. In its practice, the "Perlyna Podillya" Ltd. should focus on individual employee development plans. They should be jointly prepared by both the employee and his immediate supervisor. On this basis, it is possible to reconcile the individual's preferences and the interests of the enterprise. The choice of specific activities in the plan should be made taking into account both recommended and proven training courses.

An important direction for improving the organization of the training system in the "Perlyna Podillya" Ltd. can be the introduction of systematic control over the training process, namely its results through the study of the effectiveness of employee training.

It is advisable to conduct the sssessment of personnel training at the according to the following criteria:

- emotional evaluation of the completed training immediately after its completion;

- conscious assessment in 1 week;

- behavioral assessment that will make use of knowledge even in everyday activities;

- professional readiness to impart knowledge to colleagues;

- introduction of new technologies, where possible, into their own practical activities.

It would also be advisable to conduct regular surveys and identify training needs. This, in the end, can affect the performance of everyone and the team as a whole. And will be an effective means of motivation.

Thus, we have formulated the main, in our opinion, proposals for improving the personnel training system of the "Perlyna Podillya" Ltd., where special attention should be paid to the conditions, which will help to stimulate to increase the turnover of funds spant for staff training:

- The preparation and delivery of training requires as complete an analysis as possible of the organisation measures that will be used.

- Total effectiveness of training is not possible without the support of management.

- High results in staff training are only possible if the company keeps track of development-related issues and the development of their employees' skills.

Conclusions. In Ukraine, unfortunately, staff training is often still quite low. Although this is an important prerequisite that will provide the company with highly qualified personnel and increase its performance and economic results as a whole. However, it has some drawbacks and requires a change of approach from both the state and employers.

One of the strategic goals of modern Ukrainian companies and organizations should be to teach managers to do their own development and to manage the development of their subordinates as effectively as possible. To do this, they must: create a system of training the managers at all levels; have a clear understanding of the strategies implemented, including the personnel development strategy as a key enterprise resource; determine what personal and staff skills and competencies should be developed to achieve sustainable competitive advantage; build a coherent system of incentives and punishments aimed at developing staff in the right direction for the enterprise; have senior and middle level executives interested in both staff development and their own; be ready to create a system of implementation and integration of learning outcomes into existing business processes.

The "Perlyna Podillya" Ltd. has significant, untapped reserves to improve the organization of staff training. First of all, the staff of the company that can be involved in progressive change. There is an opportunity to use our proposed ways to improve employee training. Many of them do not require significant material costs. The main thing is the desire of the management. 


\section{References}

1. Babiak, H. P., Bentsal, Yu. M. (2014) Zarubizhnyi dosvid orhanizatsii navchannia personal [Ways to improve the efficiency of staffing organization]. Rehionalni aspekty rozvytku produktyvnykh syl Ukrainy, Is. 19, p. 130-133. [in Ukrainian].

2. Babiak, H. P., Hrytsyna, O. V. (2013) Shliakhy pidvyshchennia efektyvnosti zabezpechennia orhanizatsii formuvannia personal [Ways to improve the efficiency of staffing organization]. Rehionalni aspekty rozvytku produktyvnykh syl Ukrainy, Is. 18, p. 137-141 [in Ukrainian].

3. Babiak, H., Zaporozhan, L. (2017) Rezervy ta shliakhy pidvyshchennia orhanizatsii navchannia personalu v ustanovi [Reserves and ways to improve the organization of staff training in the institution]. Sektory ekonomiky $v$ protsesi realizatsii derzhavnoi rehionalnoi polityky: zb. materialiv dop. mizhnar. nauk.-prakt. konferentsii, 26-27 zhovtnia 2017 r., Ternopil, pp. 158-162 [in Ukrainian].

4. Hrishnova, O. A., Nesevra A. I. (2017) Molodi profesionaly na rynku pratsi: problemy harmonizatsii osobystoho zhyttia ta trudovoi diialnosti [Young professionals in the labor market: problems of harmonization of personal life and work activity]. Sotsialno-trudovi vidnosyny: teoriia ta praktyka, Vol. 1, pp. 49-60 [in Ukrainian].

5. Illiash, I. (2015) Modern methodical approaches to design the HR-management system of enterprises. The Genesis of Genius. Geneva, Switzerland, No 5, Vol. 1, pp. 21-23.

6. Nesterenko, O. M. (2010) Shliakhy vdoskonalennia profesiinoho rozvytku personalu na pidpryiemstvi [Ways to improve the professional development of staff at the enterprise]. Visnyk ekonomiky, transportu i promyslovosti, Vol. 30, pp. 87-88 [in Ukrainian].

7. Ostroverkhov, V. (2014) Pidvyshchennia konkurentospromozhnosti upravlinnia personalom yak napriam innovatsiinoi diialnosti pidpryiemstva [Improvement of personnel management competitiveness as a direction of innovative activity of the enterprise]. Rehionalni aspekty rozvytku produktyvnykh syl Ukrainy, Is. 19, pp. 100-110 [in Ukrainian].

8. Pravyla vnutrishnoho trudovoho rozporiadku pidpryiemstva "Perlyna Podillia" Ltd. [Rules of the internal work order of the enterprise of "Perlyna Podillya" Ltd.] [in Ukrainian].

\section{Література}

1. Баб’як Г. П., Бенцал Ю. М. Зарубіжний досвід організації навчання персоналу. Регіональні аспекти розвитку продуктивних сил Украӥни. 2014. Вип. 19. С. 130-133.

2. Баб'як Г. П., Грицина О.В.Шляхи підвищення ефективності забезпечення організації формування персоналу. Регіональні аспекти розвитку продуктивних сил України. 2013. Вип. 18. C. $137-141$.

3. Баб’як Г., Запорожан Л. Резерви та шляхи підвищення організації навчання персоналу в установі. Сектори економіки в процесі реалізації державної регіональної політики : зб. матеріалів доп. міжнар. наук.-практ. конференції, 26-27 жовтня 2017 р., м. Тернопіль. Тернопіль, 2017. C. $158-162$.

4. Грішнова О. А., Несевра А. І. Молоді професіонали на ринку праці: проблеми гармонізації особистого життя та трудової діяльності. Соціально-трудові відносини: теорія та практика. 2017. № 1. С. 49-60.

5. Illiash I. Modern methodical approaches to design the HR-management system of enterprises. The Genesis of Genius. Geneva, Switzerland, December 2015. No. 5. Vol. 1. P. 21-23.

6. Нестеренко О. М. Шляхи вдосконалення професійного розвитку персоналу на підприємстві. Вісник економіки, транспорту і промисловості. 2010. № 30. С. 87-88.

7. Островерхов В. Підвищення конкурентоспроможності управління персоналом як напрям інноваційної діяльності підприємства. Регіональні аспекти розвитку продуктивних сил України. 2014. Вип. 19. С. 100-110.

8. Правила внутрішнього трудового розпорядку підприємства ТОВ НВА “Перлина Поділля”.

Статтю отримано 20 червня 2019 року

Article received June 20, 2019 